todologiczno-problemowa jest inna niż dwóch poprzednich części. Należało bowiem wyjść poza dane tekstowe i skonfrontować je $\mathrm{z}$ dostępnymi danymi historycznymi znanymi $\mathrm{z}$ innych źródeł. $\mathrm{Z}$ tego względu ta część rozprawy z pewnością zainteresuje nie tylko teologów, ale również historyków pierwotnego Kościoła, a zgromadzony materiał jest naprawdę bardzo bogaty i to w oparciu o najnowszą literaturę przedmiotu. Bardzo skrótowo można go przedstawić w postaci czterech bloków tematycznych: 1. prześladowania i apostazje, 2. lapsi i poenitentia secunda, 3. ortodoksja i herezja, 4. urzędy i funkcje w Kościele. W każdym z nich odnajdziemy z pewnością wiele nowych informacji. Dodajmy do tego, że umieszczona na końcu Bibliografia (s. 485-540) gromadzi imponującą ilość pozycji nie tylko na temat Pasterza (uwzględnia również publikacje polskie), ale również obejmuje cały kontekst kulturowo-religijny tego dzieła.

Rozprawa A. Schneidera jest wybitnym osiągnięciem nie tylko w zakresie badań nad Pasterzem Hermasa - którego odtąd będziemy czytać sub specie ecclesiae - ale wydatnie ubogaca naszą wiedzę o pierwotnym chrześcijaństwie. Dlatego już posiada bardzo wysoką rangę w ocenach i trwałe miejsce w nauce.

Ks. Franciszek Szulc - Katowice

\title{
Robert GODDING, Bibliografia di Gregorio Magno (1890-1989). Opere di Gregorio Magno. Complementi 1, Roma 1990, Città Nuova Editrice, ss. X +350 .
}

Autor publikacji Robert Godding, belgijski jezuita, jest członkiem Société des Bollandistes i wykładowcą w Collège Saint-Michel w Brukseli. Praca zawiera literaturę bibliograficzną o Grzegorzu Wielkim z okresu stu lat (18901989), zebraną z okazji obchodów jubileuszu 1400-lecia wyboru Grzegorza na papieża (590). Dzieło Goddinga wymienia 2608 publikacji znawców tego Ojca Kościoła i składa się z pięciu części podzielonych na 17 sekcji. Zanim przejdziemy do prezentacji niniejszej pozycji, pragniemy w tym miejscu przypomnieć, że Autor w swoich badaniach koncentrował się przede wszystkim na przedstawieniu osoby Grzegorza Wielkiego jako teologa, egzegety, pasterza, mistrza życia wewnętrznego oraz wspaniałego administratora w trudnych czasach dla Rzymu i Italii. Ponadto R. Godding podkreśla, iż Grzegorz był pierwszym mnichem zasiadającym na rzymskiej stolicy biskupiej. W polu głównych zainteresowań belgijskiego jezuity znalazły się także zagadnienia dotyczące osobowości, kultu Grzegorza i wpływu jego twórczości na epokę średniowiecza.

W części pierwszej omawianej bibliografii (Bibliografie e miscellanea, s. 36) wymienione są publikacje sprzed roku 1890, jak również te, które ukazały się po roku 1890, aż do roku 1980, a z których korzystał Autor przy redagowaniu 
swojej pracy. Wśród nich znajdują się prace ogólne oraz szczegółowe, omawiające ściśle określoną aktywność Grzegorza. Następnie R. Godding wymienia zbiór artykułów krytycznych różnych autorów, podejmujących rozmaite wątki działalności Wielkiego Doktora Kościoła.

Część druga (Gregorio e il suo tempo, s. 9-63) rozpoczyna się od wyliczenia encyklopedii w porządku chronologicznym od 1899 do 1989 roku, z podaniem stron, które przybliżają nam postać naszego Ojca Kościoła i charakteryzują czasy, w jakich mu przyszło żyć. W dalszej kolejności Autor umieścił historie oraz słowniki poświęcone papieżom i świętym. Z zadowoleniem trzeba stwierdzić, że Godding wyliczając pozycje poświęcone Grzegorzowi, nie pominął znanych w Polsce opracowań S. M. Renaty i J. Czuja. Z kolei wymienione są artykuły wydane w związku z 1300-leciem pontyfikatu Grzegorza Wielkiego (1890) i różnojęzyczne wydania związanej z tą rocznicą encykliki Piusa X Iucunda sane (s. 28). Po przekazaniu ogólnych informacji o życiu Grzegorza, Autor wprowadza czytelnika w lata, które poprzedziły jego zasiadanie na Stolicy Piotrowej. Wymienione tutaj pozycje dotyczą rodziny Grzegorza, jego osobowości, charakteru, związków z życiem monastycznym, benedyktynami i klasztorem św. Andrzeja w Rzymie. Część ta kończy się podaniem obfitej literatury skupiającej uwagę czytelnika na latach 590-604, kiedy to Grzegorz był już Biskupem Rzymu. Spotykamy tu opracowania omawiające między innymi następujące zagadnienia: Grzegorz a Italia bizantyńska i Longobardowie, misja w Anglii (s. 52-55), Grzegorz i Wschód, zagadnienie tytułu patriarchy ekumenicznego, ekonomia i społeczeństwo (s. 61-62), następstwa pontyfikatu Grzegorza.

Najbardziej obszerną objętościowo jest część trzecia (Le opere, s. 67-195). Godding wylicza w niej dzieła napisane przez Grzegorza i omawia je według przyjętego przez siebie schematu, który powtarza się niemal przy każdej pozycji. Schemat ten zawiera następujące elementy: wydania, tłumaczenia, rękopisy, studia, język i styl, wpływ na innych autorów. W części tej znajdują się również tytuły dzieł przypisywanych naszemu Ojcu Kościoła.

W przedostatniej części czwartej (Il pensiero, s. 199-252) ukazane zostało bogactwo myśli i nauki Grzegorza Wielkiego. Z podanej literatury na ten temat wyłania się postać Grzegorza - pasterza, egzegety, teologa, antropologa i moralisty. W dalszej kolejności wymieniono opracowania świadczące o jego żywym zainteresowaniu eschatologią, angelologią, demonologią i duchowością. Na podstawie badań przeprowadzonych przez Autora, możemy stwierdzić, że Grzegorzowi nie była również obca działalność polityczna.

W części piątej (Fortuna, s. 255-283) Godding informuje nas o wpływie, jaki wywarła osoba Grzegorza na potomnych oraz pisze o hagiografii łacińskiej, greckiej i celtyckiej. W punkcie tym jest również mowa o legendach związanych z Grzegorzem, a także dane dotyczące jego kultu, grobu, napisu na grobie i materialnych świadectwach o nim. Autor kończąc swoje rozważania, zajął się 
pokrótce problemem ikonografii a ponadto dołączył do pracy indeks autorów $\mathrm{i}$ indeks analityczny.

Warto w tym miejscu podkreślić, że Wydawnictwo Città Nuova Editrice rozpoczęło recenzowaną przez nas pozycją ambitny plan, by w kolejnych tomach wydać łacińsko-włoską edycję wszystkich dzieł Grzegorza Wielkiego.

Zaprezentowany układ poszczególnych części omawianej książki, kształtował się pod wpływem zebranej literatury. Jest on także owocem długich i żmudnych poszukiwań przeprowadzonych w bibliotekach Rzymu, Włoch i Belgii. Praca jest oryginalnym dziełem Goddinga, choć on sam stwierdza (Wprowadzenie, s. VII), że dokonany przez niego podział jest zbliżony do bibliografii, sporządzonej przez Leclerqa (J. Leclerq, La spiritualità del Medioevo [VI-XII secolo]. Da s. Gregorio a s. Bernardo, Bologna $1986^{2}$, p. 29). Wśród osób, którym Godding składa podziękowanie za pomoc, znajduje się również ks. prof. M. Starowieyski, mający swój udział w zebraniu polskojęzycznych publikacji. Belgijski jezuita wyraża nadzieję, że drugie wydanie tej Bibliografii, zostanie uzupełnione o brakujące tytuły, pominięte w wydaniu pierwszym i wzbogacone o nowe. Jeśli ta idea zmaterializuje się, wówczas można będzie dostarczyć Autorowi jeszcze wiele „starych” (do roku 1989), jak i „nowych” opracowań o Grzegorzu w języku polskim, które można znaleźć choćby w Polskiej bibliografii antyku chrześcijańskiego, publikowanej w kolejnych tomach „Vox Patrum” począwszy od tomu 24-29. Po roku 1989 ukazało się o Grzegorzu Wielkim szereg nowych polskich publikacji takich autorów, jak S. Sojka, E. Staniek, M. Chuchra, czy też rozprawa doktorska T. Wolińskiej (Stosunki papieza Grzegorza Wielkiego $z$ dworem cesarskim i administracja bizantyńska, Piotrków Trybunalski 1998, Wydawnictwo Filii Kieleckiej WSP, ss. 272). Należy stwierdzić, że recenzowana przez nas Bibliografia jest bardzo użytecznym narzędziem pracy nie tylko w bliższym poznawaniu teologicznej spuścizny naszego Wielkiego Ojca i Doktora Kościoła, ale także w innych studiach patrystycznych i historycznych.

Ks. Henryk Dybski - St. Petersburg

\section{Ks. Franciszek DRĄCZKOWSKI, ABC pisania pracy magisterskiej [z patro- logii], Pelplin 2000, Bernardinum, ss. 78.}

Zanim przejdziemy do przedstawienia treści zawartych w tej książce, chcielibyśmy zwrócić uwagę na wyjątkowe znaczenie prezentowanej publikacji. Ksiądz Profesor Drączkowski jest bowiem, tak się wydaje, pierwszym z teologów, który zdecydował się - i słusznie! - na opracowanie ,przewodnika”, który ma służyć studentom sposobiącym się do pisania pracy magisterskiej w ramach jednego z działów teologii, a mianowicie patrologii. Należałoby sobie życzyć 